\title{
Pervasiveness and Different Characteristics of Cestode, Confluaria capillaris (Rudolphi, 1810) from Jungle babbler, Turdoides striata at Sindh, Pakistan
}

\author{
Wali Muhammad Mangrio ${ }^{1}$, Hakim Ali Sahito ${ }^{2 *}$, Tasneem Kousar ${ }^{2}$, Aziz Ullah ${ }^{3}$, \\ Faheem Ahmed Jatoi ${ }^{2}$, Zafar Hussain Shah', Bilawal uddin Ghumro ${ }^{2}$ \\ ${ }^{1}$ Paras Public Higher School Kandiaro District: Naushahro Feroze, Sindh - Pakistan. \\ ${ }^{2}$ Department of Zoology, Faculty of Natural Sciences, Shah Abdul Latif University, Khairpur, Sindh - Pakistan. \\ ${ }^{3}$ Department of Entomology, Faculty of Agriculture Sciences, Lasbella University of Agriculture, Water and \\ Marine Sciences, Uthal, Balochistan - Pakistan.
}

*Corresponding Author: Hakim Ali Sahito, Department of Zoology, Faculty of Natural Sciences, Shah Abdul Latif University, Khairpur, Sindh - Pakistan

\begin{abstract}
During an investigation on the on the helminth parasite, a species of cestode belongs to the genus; Confluaria Ablasov Spasskaja, 1966 was recovered from the large intestine of the host bird Jungle babbler; Turdoides striata from District: Naushahro Feroze, Sindh, Pakistan during 2015-16. For this purpose $(n=36)$ host birds were disected of which (n=96) specimens were collected and few number of parasites were found in anterior as well as median part but most of the parasites were found in the terminal part of the large intestine, near the clocal opening. The specimens were observed unrelated from the congress of other cestode species but in external appearance having closely resemblance with Confluaria capillaris, (Rudolphi, 1810) which consist larger body size and segments, maximum width is found in gravid segments. When worms were alive they were whitish, delicate and opaque in body appearance and the muscular scolex wider than long and only single rows of the hooks in their rostellum and larger neck followed by 230 segments. Immature segments were maximum in numbers than the mature segments and all were wider than long. A larger rostellum along with rostellular sac and vitelline gland was seen in compact form. Also muscular suckers, cirrus sac proturated shape and dome shaped ovary, eggs were spindle shaped and tests oval in shape. The high perseverance was observed in hot summer season during the month of June and August, compared winter season with the major distinction $(P<0.05)$ in the whole number of the host birds. It is concluded that, many species of passeriformes hold wide range of helminth burden in their internal visceral organs it is firm call to carry out the systematic based study on the variety of helminth that lodges the high infection to these host species.
\end{abstract}

Keywords: C. Capillaris, Rostellum, Scolex, Clocal opening, Dome shaped.

\section{INTRODUCTION}

Birds are found throughout the world, they are found in every altitudes and habitats such as; grassy fields, marshy places, trees, open oceans and savannah. Functional traits relay the impact on the species to contribute to their ecosystem and hence these traits are referred functional traits. The traits diet is the most functional trait i.e., nectarivores in pollination, furgivorus in contributing to seed dispersal and insectivores to pest control (Greenberg et al., 2000; VanBael et al., 2003, 2007; Sekercioglu, 2006). Agricultural products are the chief source for their food which comprises vegetation of the crop plants, fruits, grains, insect, arthropods, rodents (Connor and Shrubb, 1986). And in-sufficient amount of food and water impart negative role on the quality and quantity of the birds (Western and Grimsdell, 1979). The study of ornithology has important role because in bird species having high metabolic rate for that purpose they having high need for their food, also role in cross pollination of certain trees (Elon and Fred, 1924). They eat rodent and poisonous insects, which are most harmful for the crops because birds may serve their life on the high mountains and they 
having variation in their ecology, habitat, appearance, habit and distributions (Whelan et al., 2008). Jungle babbler, Turdoides striata belongs to the Leiothrichidae family and Indian Sub-continent is their sweatable habitat, they are commonly occurs in small groups six to ten may be much more they gregarious in their nature and locally called Saath Bhai (Seven brothers) (Henry, 1903) and in Hindi and Bengali they are also called seven sisters (Henry and Burnell, 1903). They are dirty in their colouration (Andrew and Naik, 1965; Narang and Lamba, 1986; Bhavna and Geeta, 2010). Their favourable food is insect but some species may eat other smaller vertebrates including lizards often found in gardens, forests and cities, attain after the passing three years they attain the sexual maturity and can breed any season of the year, finally female left their natal group after the passing of two years and play chases and make fun of flights (MacArthur and MacArthur, 1961). Sexually they are identical with drably colour and yellow bill and upper most region of the body is slightly darker and little molt occurs on the breast and throat and may feed the larvae of several arthropod organisms (Srivastava, 2013).

Most of the parasites inter in to the body of aves due to impurity in their food, inadequate management, coccidiasis, inefficient exposure to air are the main factors (Abebe et al., 1997; Nadeem et al., 2007). When parasites become successful in inference to their host body and finally may kill to their host. Helminths cause great infection in both wild and domestic birds (Katakam et al., 2010). Many host species can transfer same type and species of parasite to each other (Holt and Lawton, 1994) and due to this reaction great loss occurred in meet, quality and quantity (Yazdanbakhsh et al., 2002; Adang, 1789). Lot of work had been conducted on the presence of cestode helminths from numerous bird species; many Indian birds were examined by (Mcjunkin et al., 2003) and observed flariid worms from the intestine of the avian host, viral and bacterial infections were observed in the Crested ibis (Zhou et al., 2000; Xi et al., 2002; Seguel et al., 2012; Fan et al., 2002) and guinea fowls of Limpopo province belonging to the Guttera pucherani and Numididae were checked by (Junker $e t$ al., 2008) who observed different cestode species i.e., Raillietina sp., Abuladzugnia guttera, $R$. steinhardti, Davaineanana, $R$. pintneri, Hymenolepis cantaniana, $R$. angusta, Numidella numida, Porogynia paronia, Ortleppolepis multiuncinata and Octopetalum numida. Similarly, nematode species; Tetrameres numida, Ascaridia numidae, one unidentified subulurid, Cyrnea parroti, Subulura sp. Gongylonema congolense, S. suctoria, Hadjelia truncate, S. dentigera and Sicarius caudatus during their research work only one species acanthocephlon (Mediorhynchus gallinarium) and one trematode belonging (Dicrocoelium macrostomum) found from the liver of the host of which Abuladzugnia guttera, M. gallinarium, Ortleppolepis multiuncinata, Sicarius caudatus, and G. congolense were the first documentary from guinea fowls and Hadjelia truncate, Dicrocoelium macrostomum and G. congolense were the first report from Single Crested guinea fowl at South Africa. (Gerald et al., 1968) observed shore birds and found new species of cestode H. deblocki n. sp from the host Short-billed dowitcher was differ in morphological basis from other species of cestodes which were observed from the another hosts and also found eighteen species of trematodes and nematodes identified species. Corvus brachyrhynchos in Ohio by (Joseph, 1968) disected (339) host birds and observed (31) helminth parasite species of cestodes and nematodes of which, (12) helminth parasites were previously un-observed from this host. Nematode species; P. sexalatus, $S$. quiscali, $S$. flexivaginalis, A. laminosioptes hymenopterus $S$. bipectinatus, A. corvinus and $G$. delibata and cestode species; $O$. rostellata and $H$. Serpentulus, Great Antillean grackle was examined by (Whittaker, 1973).

There is little work had been conducted on the internal helminth parasites of Jungle babbler throughout the world because this species is not a cosmopolitan only found in Indian sub-continent and their little surroundings only one record of the internal helminth parasite of this species is found in the documentary. (Shuvajit et al., 2012) reported a trematode species Zonorchis sanglaensis n. sp., in the gall bladder of the host at Himachal Pradesh, India. (Ghazi et al., 2002) worked on common pigeon (Rock dove) at Karachi, observed a new species of cestode, Pulluterina Karachiensis. Similarly, other documentary regarding the helminth infection in aves are available in Pakistan (Fahimullah, 1965; Khan and Habibullah, 1967; Yousaf and Baig, 1974; Haider et al., 1980; Pal and Ahmed, 1985) and little record about cestode of duck (Bilqees and Rehana, 1977) and wild birds (Bilqees and Sultana, 1974; Bilqees and Jehan, 1977) including two from Acridotheres tristis (Khan and Habibullah, 1967; Khanum et al., 1982) from Karachi. Therefore, little work had been conducted 
on the feeding behaviour of Jungle babbler but no work previously had been conducted to find out the internal helminth infection of this host bird throughout the avifauna world as well as in Pakistan and province Sindh at District Naushahro Feroze.

\section{Materials AND MethodS}

The Jungle babbler, T, striata were captured during, 2015-16 for the purpose to carry out the study of internal helminth infection and their burden and to find out the internal organ of the body of the host where the helminth affect the visceral organs. A total of $(n=36)$ birds were captured from the different location of District: Naushahro Feroze, Sindh province and after the dissection a total of $(n=96)$ specimen were found from above whole birds. Most of the host birds were purchased from the local people of the rural areas of the surrounding, while as some were hunted by using air gun and some were caught by traps and nets. Either few were hunted by wooden made apparatus locally called (Gullel). In case some of them suppose to be dead a very instantly they were kept in refrigerator for short time but on priority basis dissected. Those who had died by the hunt of airgun and the alive birds were kept in wooden or iron made cage for few days, supplied them food and water as their needed based and when those were necessary disected as per need basis. In priority basis dead and alive birds were brought to the Parasitology laboratory, Department of Zoology, Shah Abdul Latif, University, Khairpur and the experimental process was started. In initial basis few glass slides were sterilized, cleaned with 100\% ethanol and left them 15-20 minutes in a coplin jar, then slides were tacked out from the coplin jar and dried also cleaned with the handkerchief, cotton swab or spongy piece of cloth. Later on, tacked another cotton swab and few drops of chloroform released on the cotton swab and very carefully by the help of one hand the host were forcefully hold and by another hand the cotton swab were kept on the both nostrils near the beak for the anaesthetization purpose and now few amount of distilled water were kept in few pattery plates and arranged them in manner way. Feathers were removed from the clocal opening to the neck regions with the help of forceps a longitudinal cut was given and nearly till to neck region. Whole internal organs were tacked out from their internal frame work of the body and every organ of the host body separately kept in pattery plates. Which contained already normal saline solution, and with the help of stereo dissecting microscope each internal organ was very carefully examined. Then specimen of cestodes were laid on the glass slides, covered by cover slip and string of thread wrapped thoroughly over the cover slip and kept slides in coplin jar containing ethanol and left slides for 10-12 hours. The passing of above time thread were reopened and few drops of borax carmine released in next pattery plates and slide containing parasites were poured in borax for colour mounting when specimens were mounted then parasites were washed by ethanol two to three time. Only one or two drops of Canada balsam were put on the glass slide and laid the parasite on slide and covered by cover slip. Consequently, slides were kept in oven box for one night by applying suitable temperature and the diagram of specimens were made through the help of Camera Lucida. Then photography of the specimens were taken with camera Meiji infinity, 1DK-3000 and measurements of the whole specimen and their internal architecture were taken in millimetres, $(\mathrm{mm})$ but estimation of the eggs was measured in micrometers $(\mu \mathrm{m})$. In response of challenges permanent slides of present specimen i-e., Holotype of specimens were placed in the Parasitology Laboratory, Department of Zoology, SALU, Khairpur for reference motivation.

\section{Statistical analysis:}

Finally, whole data were inserted in MS, excel spread sheet and then imported for analysis of variance for examination the significant results which were made with the help of (USA) software, 8.1, version SXW.

\section{RESUlts}

\section{Systematic position:}

Family: Hymenolepididae Railliet and Henery, 1910; Sub-Family: Hymenolepidinae Perrier, 1897; Genus: Confluaria Ablasov Spasskaja, 1966; Confluaria capillaris Rudolphi, 1810; Location: Large intestine; Host: Jungle babbler; Turdoides striata; Locality: Naushahro Feroze, Sindh, Pakistan; Number of specimen: 96 from 36 birds. Finally the collection, dissection, measurements, identification and mountings were made according to given procedure. 
Pervasiveness and Different Characteristics of Cestode, Confluaria capillaris (Rudolphi, 1810) from Jungle babbler, Turdoides striata at Sindh, Pakistan

\section{Description:}

The specimens were collected from the intestine Jungle babbler length of worm measured 50.55 by 1.012 in size. Maximum width was at the level of gravid segments. Worms were relatively delicate, whitish and opaque when alive. Scolex muscular, wider than long measured, 0.26 6by 0.347 were in size. Rostellum provide single row of 7 hooks measured $0.047-0.052$ X $0.011-0.009$ in size. Lager neck present measured 0.204 by 0.571 in size. Neck followed by series of 230 segments. Gravid segments were 162 in number measured 0.891-1.114 X 0.437-0.505. Mature proglottids are 56 in number measured 1.029-1.062 X 0.372-0.478. All segments were wider than longer. Rostellum measured 0.023 by 0.057 in size. Rostellum sac measure 0.1 by 0.223 in size. Suckers were muscular measured 0.090-0.119 X 0.109-0.133 in size. Vitelline gland compact measured 0.275- 0.323 X 0.064 -0.072 in size. Ovary dome shaped measured $0.154-0.162$ X $0.275-0.291$ in size. Cirrus sac proturated measured $0.421-0.486 \times 0.121-0.170$ in size. Tests three to four in numbers, oval in shape measured $0.154-0.210$ X $0.170-0.195$ in size. Egg measured $0.042-0.068$ X $0.025-0.042$ in size.
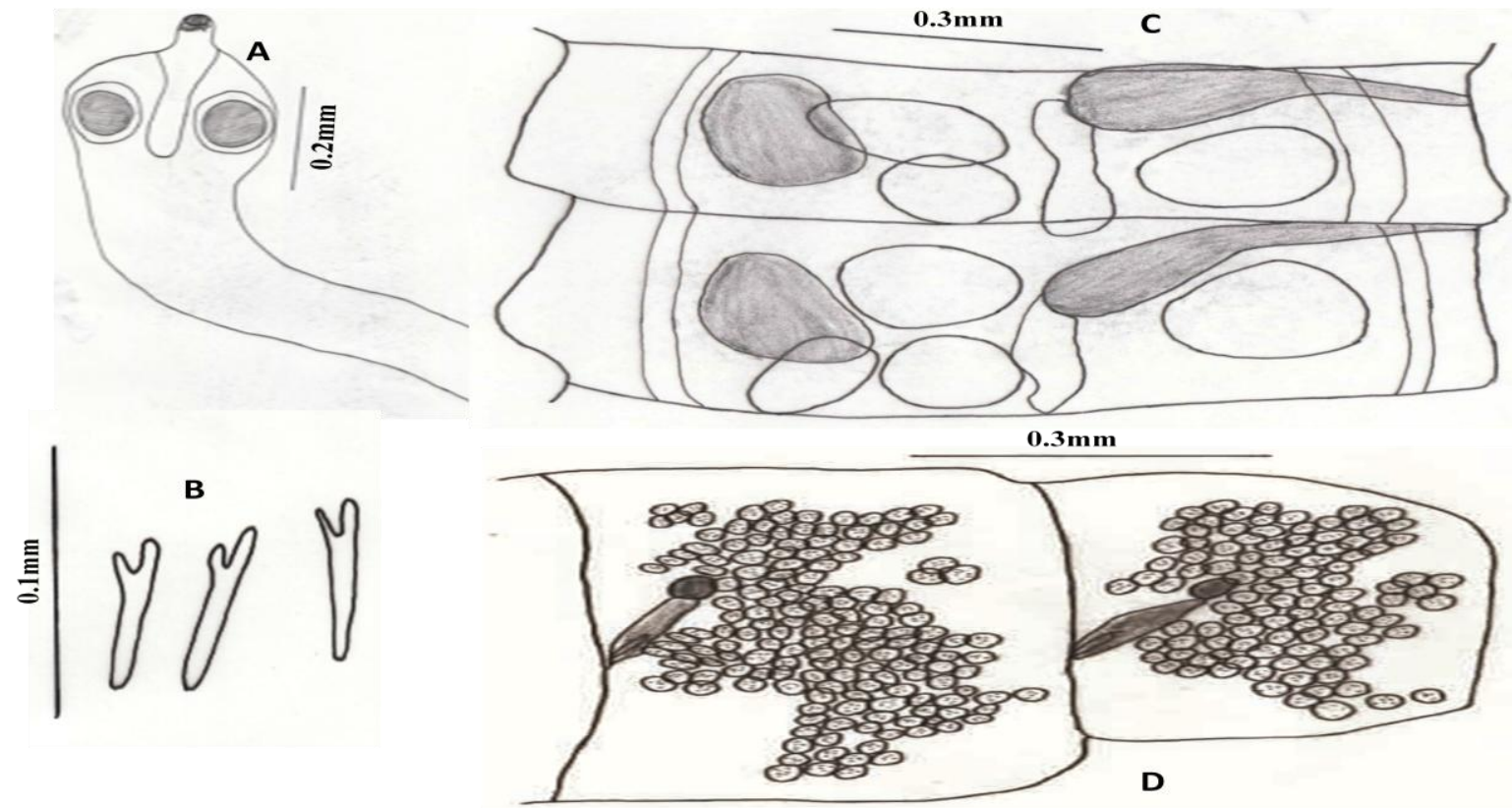

Confluaria capillaris Rudolphi, 1810; A: Scolex; B: Hooks; C: Mature segment; D: Gravid segment
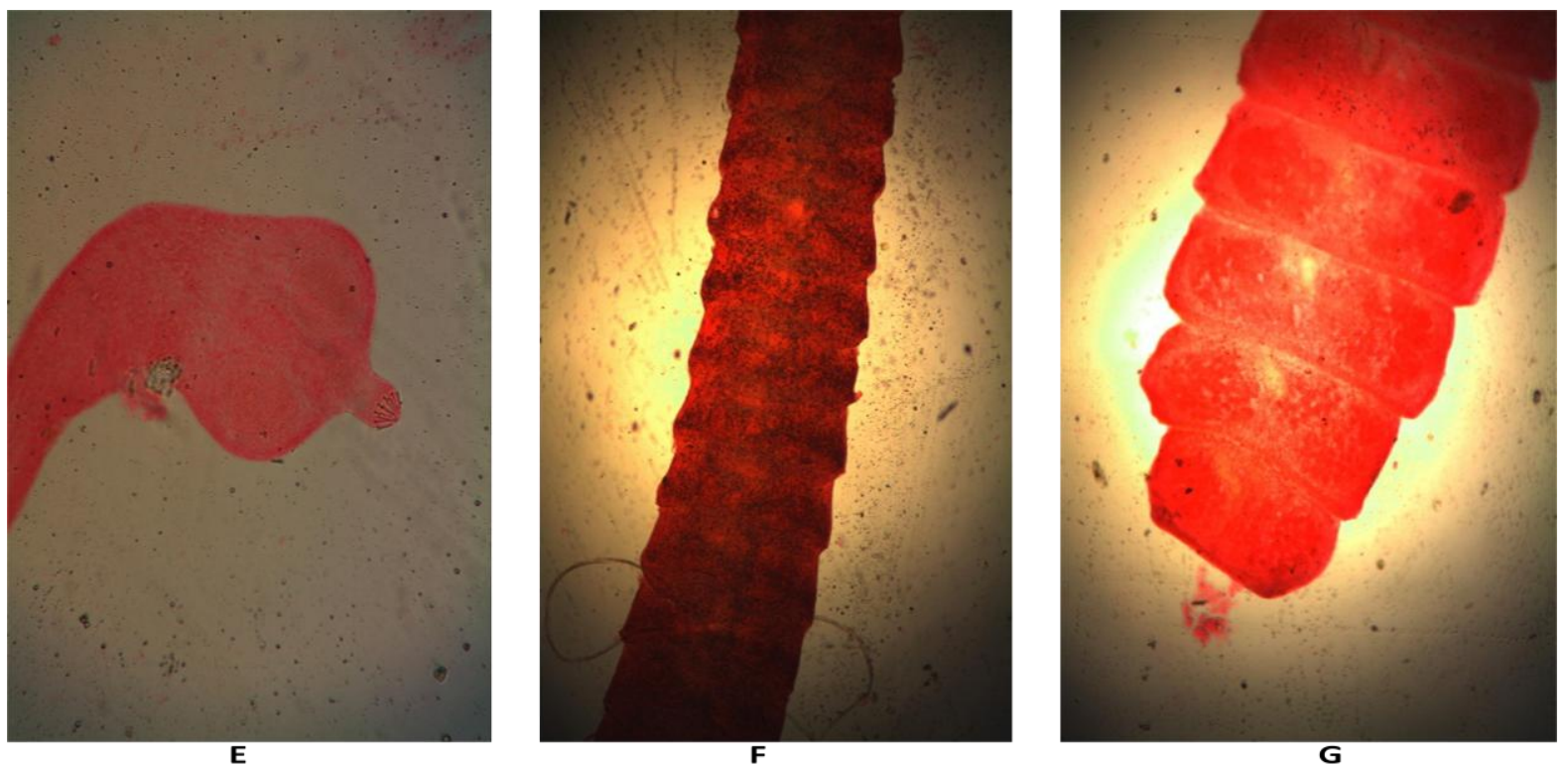

E: Scolex; F: Mature segment; G: Gravid segment 
Pervasiveness and Different Characteristics of Cestode, Confluaria capillaris (Rudolphi, 1810) from Jungle babbler, Turdoides striata at Sindh, Pakistan

\section{Remarks:}

The genus; Confluaria Ablasov Spasskaja, 1966 was erected to accommodate the cestodes of birds. Type species was $C$. spasskii (Ablasov, 1966) collected from the Aythya fuligula of Kazakhstan. Other species include; Confluaria podicipina collected from P. grisegena and T. ruficollis in Bulgaria; same species found in P. cristatus and P. nigricollis (Macko, 1959; 1962) at Slovak Republic; from $P$. nigricollis (Chiriac, 1960) at Romania; P. cristatus and P. nigricollis (Rysavy, 1961) in Czech Republic and P. nigricollis (Rysavy and Sitko, 1929) at Czech Republic; from Fulica atra (L.) (Nikogosyan, 1981) at Armenia; C. Furcifera. (Simeonov et al., 1990) observed from P. nigricollis (von Linstow, 1908) in Germany; also reported from Podilymbus pdiceps (Mahon, 1956) at Canada; at Denmark; recovered from Tachybaptus ruficollis at Burgas. And also reported from P. cristatus (Macko, 1959) at Switzerland; from P. cristatus and P. grisegena (Korpaczewska, 1960) at Poland from $P$. auritus (Spasskaya, 1965) in Russia recovered from P. cristatus (Galkin, 1986) at Kurish Spit, Baltic coast from $P$. grisegena (Stock and Holmes, 1987). In Canada collected from P. cristatus (Rysavy and Sitko, 1995) in Moravia, Czech Republic; and P. cristatus in Europe; Confluaria multistriata reported from the host; T. ruficollis (Rudolphi, 1810), locality un known; T. ruficollis (Rudolphi, 1819), locality un known; P. cristatus (Fuhrmann, 1926). In India also from unidentified bird (Coot) (Solomon, 1932) at Kenya also from T. ruficollis capensis, (Singh, 1959). In India; from $P$. nigricollis and P. cristatus (Rysavy, 1961) in Czech republic; collected from T. ruficollis Dollfus, 1961). At France; recovered from Tachybaptus ruficollis (Gomez and Lopez-Roman, 1980) in Spain and collected from P. auritus and Tachybaptus ruficollis (Borgarenko, 1982). At Tajikistan from Clangula clangula (L.) (Anseriformes: Anatidae) in Kamchatka recovered from T. ruficollis (Galkin, 1986) an in Baltic Sea coast and also recovered from P. cristatus (Rysavy and Sitko, 1995). In Czech republic; Confluaria japonica collected from the host; T. ruficollis japonicus (Yamaguti, 1935). In Japan also from the same host T. ruficollis (Borgarenko, 1972) at Tajikistan; reported from T. ruficollis japonicus (Yamaguti, 1940). At Japan recovered from P. grisegena (Joyeux and Baer, 1950), in Tunis; and T. ruficollis (Kugi, 1987). In Japan; Confluaria capillaris recovered from the host; from $P$. auritus and $P$. grisegena (Rudolphi, 1819), from un known locality; from P. auritus Rudolphi, 1810), also from un known locality; recovered from the host $P$. auritus (Krabbe, 1869). At Iceland collected from T. dominicus (Fuhrmann, 1906), Brasil also from P. nigricollis (Macko, 1959), Slovak Republic recovered from P. nigricollis and P. cristatus (Rysavy, 1961), Czech republic from P. nigricollis (Gvozdev, 1965), in Kazakhstan and P. cristatus (Rysavy and Sitko, 1992) at Czech Republic. Present specimens were different from the Confluaria podicipina (Syzmanski, 1905). Spasskaya, 1966 collected from the small intestine of Podiceps nigricollis of Ukraine having smaller in body size; Scolex larger in size sucker smaller in size rostellum sac larger in size hooks were large in size; tests two to three in numbers smaller in size; cirrus sac smaller in size; Vitellaria smaller in size.

Present species were further differ from the Confluaria pseudofurcifera Vasileva, Georgiev and Genov, 2000 collected from the intestine of Podiceps cristatus Ukraine having body in smaller size; Scolex smaller in size; suckers smaller in size; rostellum mushroom like and larger in size; rostellum sac smaller in size; hooks smaller in size; tests two to three usually triangular and smaller in size; cirrus sac larger in size; Vitellarium smaller in size, also differ from Confluaria multistriata (Rudolphi, 1810). Spasskaya, 1966 collected from the intestine of Tachybatus ruficollis of Ukraine. Having body in smaller size; Scolex larger in size; sucker larger in size; rostellum larger in size; rostellum sac larger in size; hooks larger in size; tests smaller in size; cirrus sac smaller in size; Vitellaria smaller were also in size. Present cestode helminth was further differ in distinguish characteristic than Confluaria Krabbei Vasileva, Kornyushinet Genov, 1999 collected from the intestine of Tachybatus ruficollis of Ukraine having body in larger size; Scolex larger in size; sucker smaller in size; rostellum larger in size; rostellar sheath larger in size; hooks were smaller in size; tests smaller in size; cirrus sac smaller in size; Vitellaria also smaller in size.

The present sp., is change in certain characteristic than Confluaria furcifera (Krabble, 1869) Spasskaya, 1966 collected from the intestine of Podiceps grisegena of Bulgaria having body in smaller in size; Scolex smaller in size; sucker smaller in size. The rostellum larger in size; rostellum sac smaller in size; hooks smaller in size; tests two to three compact and smaller in size; cirrus sac smaller in size. Also different than Confluaria Japonica (Yamaguti, 1935). Spasskaya, 1966 collected from the intestine of Podiceps ruficollis japonicus of Japan having larger body in size; Scolex 
Pervasiveness and Different Characteristics of Cestode, Confluaria capillaris (Rudolphi, 1810) from Jungle babbler, Turdoides striata at Sindh, Pakistan

rounded and smaller in size. Thus the sucker smaller in size; rostellum larger in size; rostellar sheath smaller in size; hooks smaller in size; tests compact, triangular and smaller in size; cirrus sac envaginated and smaller in size. Whereas; Vitellarium oval and smaller in size; ovary compact eggs elliptical and this cestodes different than Confluaria capillaris (Rudolphi, 1810) collected from the intestine of Podiceps auritus differ from present species having body in smaller size. Scolex found smaller in size; sucker smaller in size; hooks smaller in size; tests smaller in size; cirrus sac smaller in size; Vitellaria also smaller in size. On the morphological basis, present specimens have close resemblance with Confluaria capillaris (Rudolphi, 1810) and identified as such. However, this specie was being reported for the first time from Pakistan and Jungle babbler (Turdoides striata) was new host record for the genus; Confluaria capillaris (Rudolphi, 1810) (Table -1), respectively.

Table. 1. Comparative morphological features and measurements of Confluaria species under laboratory conditions during, 2015-16.

\begin{tabular}{|c|c|c|c|c|c|c|}
\hline Species & $\begin{array}{l}\text { Present } \\
\text { species }\end{array}$ & \begin{tabular}{|l} 
C. podicipina \\
(Syzmanski, 1905) \\
Spasskaya, 1966
\end{tabular} & $\begin{array}{l}\text { C. pseudofurcifera } \\
\text { Vasileva, Georgiev } \\
\text { \&Genov, } 2000\end{array}$ & $\begin{array}{l}\text { C. multistriata } \\
\text { (Rudolphi, 1810) } \\
\text { Spasskaya, } 1966\end{array}$ & $\begin{array}{l}\text { C. furcifera } \\
\text { (Krabble, 1869) } \\
\text { Spasskaya, } 1966\end{array}$ & $\begin{array}{l}\text { C. Japonica } \\
\text { (Yamaguti, 1935) } \\
\text { Spasskaya,1966 }\end{array}$ \\
\hline Body & $\begin{array}{l}45.51-50.55 \\
X 0.09- \\
1.012\end{array}$ & $16-51 \times 0.21-0.43$ & $221-234$ X 0.8-1.0 & $10-15$ X $0.4-0.7$ & $27-38 \times 0.2$ & $113 \times 0.7$ \\
\hline Hooks & \begin{tabular}{|l|}
7 in number \\
$0.04-0.05 X$ \\
$0.01-0.09$
\end{tabular} & 10 hooks 0.04 X 0.06 & 10 hooks $0.03 \times 0.03$ & $\begin{array}{l}10 \text { in number } 0.04 \\
\mathrm{X} 0.05\end{array}$ & $\begin{array}{l}10 \text { in number } 0.02 X \\
0.02\end{array}$ & $\begin{array}{l}10 \text { in number } 0.03- \\
0.04 \times 0.03-0.04\end{array}$ \\
\hline Neck & $0.20 \times 0.57$ & Unobserved & Long & Unobserved & Long & Long \\
\hline Scolex & $0.26 \times 0.34$ & $0.19-0.39 \times 0.19-0.26$ & $0.18-0.23 \times 0.16-0.18$ & $0.28-0.36$ X $0.25-0.34$ & $\begin{array}{l}0.17-0.20 \times 0.14- \\
0.16\end{array}$ & $0.21 \times 0.24$ \\
\hline $\begin{array}{l}\text { Rostellu } \\
\mathrm{m}\end{array}$ & \begin{tabular}{|l|}
$0.02-0.05 X$ \\
$0.1-0.22$
\end{tabular} & $0.09-0.14 \times 0.08-0.12$ & $0.10-0.12 \times 0.05-0.06$ & $0.23-0.28 \times 0.14-0.17$ & $\begin{array}{l}0.07-0.09 \times 0.04- \\
0.05\end{array}$ & $0.16 \times 0.13$ \\
\hline Suckers & $\begin{array}{l}0.09-0.11 X \\
0.10-0.13\end{array}$ & $0.07 \times 009$ & $0.06 \times 0.07$ & $0.10 \times 0.12$ & $0.04 \times 0.05$ & $0.08 \times 0.08$ \\
\hline $\begin{array}{l}\text { Cirrus } \\
\text { sac }\end{array}$ & \begin{tabular}{|l|}
$0.42-0.48$ \\
$X 0.12-0.17$
\end{tabular} & $\begin{array}{l}0.09-0.13 \times 0.008- \\
0.01\end{array}$ & $0.26-0.30 \times 0.01-0.01$ & $0.14-0.16 \times 0.01$ & $\begin{array}{l}0.10-0.11 \times 0.01- \\
0.01\end{array}$ & $\begin{array}{l}0.19-0.30 \text { X 0.04- } \\
0.06\end{array}$ \\
\hline Ovary & $\begin{array}{l}0.15-0.16 \\
X 0.27- \\
0.29\end{array}$ & Median & Median & Median & Median & Median \\
\hline Tests & $\begin{array}{l}0.15-0.21 \\
X 0.17- \\
0.19\end{array}$ & $0.01 \times 0.02$ & $0.04 \times 0.06$ & $0.04 \times 0.05$ & $0.02 \times 0.02$ & $0.03 \times 0.04$ \\
\hline \begin{tabular}{|l}
$\begin{array}{l}\text { Vitelline } \\
\text { gland }\end{array}$ \\
\end{tabular} & \begin{tabular}{|l|}
$0.27-0.32 \mathrm{X}$ \\
$0.06-0.07$
\end{tabular} & $0.02-0.03 \times 0.01-002$ & $0.05-0.07 \times 0.03-0.03$ & $0.04-0.05 \times 0.03-0.04$ & Unobserved & $\begin{array}{l}0.05-0.07 \text { X } 0.03- \\
0.04\end{array}$ \\
\hline Eggs & $\begin{array}{l}0.04-0.06 \\
X 0.02- \\
0.04\end{array}$ & Absent & $23-28 \times 15-18$ & $34-39 \times 28-31$ & Numerous & Oval, numerous \\
\hline Host & $\begin{array}{l}\text { Turdoides } \\
\text { striata }\end{array}$ & Podiceps nigricollis & Podiceps cristatus & Tachybatus ruficollis & Podiceps grisegena & $\begin{array}{l}\text { Podiceps ruficollis } \\
\text { japonicus }\end{array}$ \\
\hline Locality & $\begin{array}{l}\text { N. Feroze, } \\
\text { Sindh }\end{array}$ & Ukraine & Ukraine & Ukraine & Bulgaria & Japan \\
\hline
\end{tabular}

The research based study was performed throughout the year started from the month April 2015 to March, 2016 and total number of thirty six wild bird Jungle babbler were captured from different localities and dissected to find out the helminth burden in their internal body tract and the information was taken at fortnightly basis. In this regard in every month three host birds were dissected in every month to check internal parasite from the host. The internal examination demonstrated that the highly infection rate was observed in the months of Hot summer, July and August during, 2015 but intense population of the parasite was observed in the month of July as well. The analysis of difference showed the difference among all the months throughout the year $(\mathrm{P}<0.05)$, respectively (Fig. 1). 
Pervasiveness and Different Characteristics of Cestode, Confluaria capillaris (Rudolphi, 1810) from Jungle babbler, Turdoides striata at Sindh, Pakistan

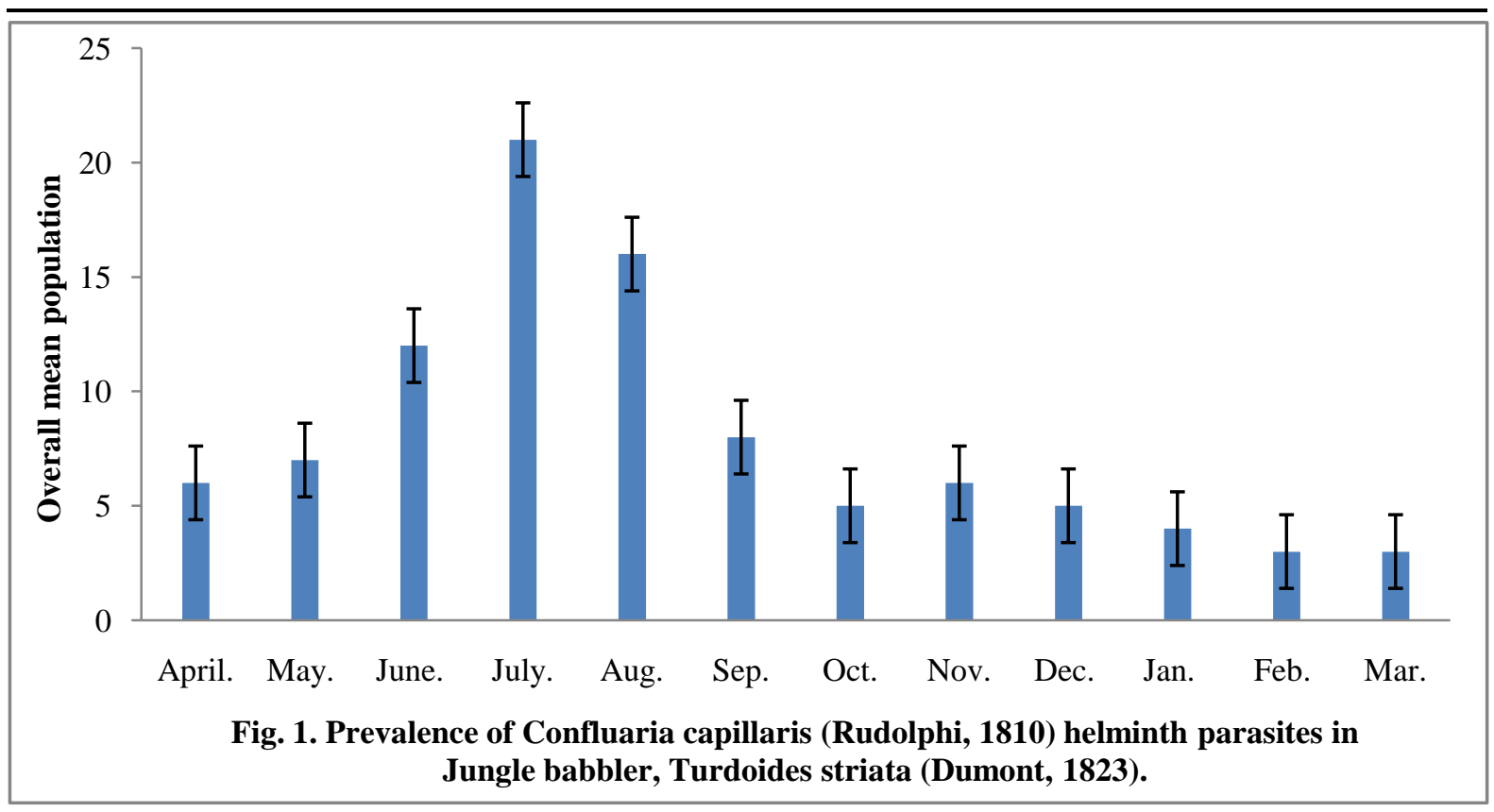

Photo gallery of research under vitro and vivo conditions

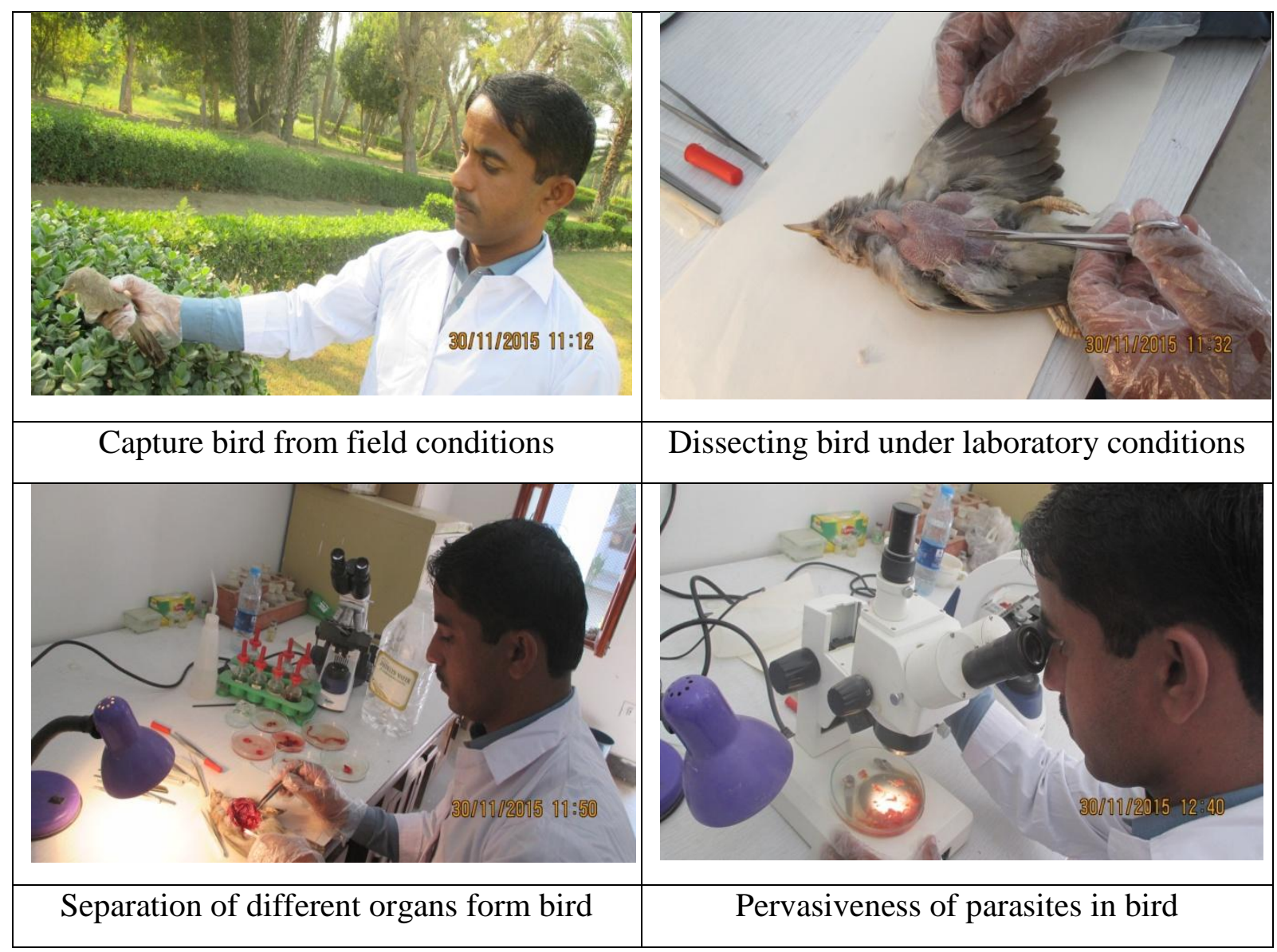

\section{DISCUSSION}

$T$, striata is the most beneficial bird for agro forest ecosystem and former friendly bird. This species of birds having positive role in agro field belonged family Leiothrichidae and widely found in Indian sub-continent and their few surrounding terrorises including Pakistan and Bangladesh as well. The examination process was initiated during, 2015-16 and birds were collected from five Talukas of District: Naushahro Feroze, namely, Naushahro, Moro, Kandiaro, Bhiria and Mehrabpur. The prevalence of parasites were observed during this study because no anyone bird was observed without infection but the high infection rate was seen in the summer months as compared with cooler season. 
Furthermore, same type of research was also performed by (Mangrio et al., 2015) who found the appearance of trematode, Lyperosomum longicauda (Rudolphi, 1809) in jungle babbler, T, striata (Leiothrichidae) bird at Naushahro Feroze - Sindh. The food consist of this bird species are small insects and their larvae and babbler who belongs to family, Timaliidae are insectivores and they are considered as co-operative in their breeding habit, commonly seen in flocks specially in non-breeding season. Some studies in their feeding behaviour shows that they are also playing role in biological control and having impact on insect pest on that basis they considered as beneficial to crops. These birds are beneficial to crops which in shape of insect pests which destroy the plants (Bharucha and Padate, 2010). The babblers are generally omnivorous, move on the land in creepy crawling way and uplifting segment of foods their eating purpose in this way they can feed seeds, grains, nectars, organic products, berries, green top last leaves on the surface of the ground. Beside the available literature of bird helminth parasites shows that the birds, Turdoides striata have not been properly investigated in Pakistan.

However, in Pakistan many scholars since from the many years they had been observed variety of species for the presence of helminth parasites in their internal organs of the body but in case of helminth infection of wild bird poorly work has been conducted and in this regard (Bilqees, 1985). The thirty six domestic and wild species of birds and also observed common Myna and from the intestine a new genus and species of cestode (Neochinorhynchotaenia sindhensis) n. gen. n. sp. was observed near at Kalri lake, Sindh and through the examination it was concluded that, this kind of hymenolepid cestode having closely resemblance with sub-family Echinorhynchotaeninae which only comprises one genus; Echinorhynchotaenia Fuhrmann. Therefore, Neoechinorhynchotaenia was regarded as new genus and the species name; $N$. sindhensis indicated the host locality. (Bilqees et al., 2004) and (Begum and Sehrin., 2012) worked on Columba livia, at Bangladesh and a total of (60) pigeons of which 35 females and 25 males were disected and all hosts were found infected by (11) species of helminth parasites of which (6) species of cestoda namely; C. cuneata (100\%), $H$. columbae (63.33\%), C. celebesensis $(68.33 \%)$, R. echinobothrida (100\%), R. cesticillus (100\%) and $R$. bonini one species of nematode; Ascaridia columbae (28.33\%) and (4) species of trematode namely; Echinoparyphium recurvatum (8.33\%), Echinostoma revolutum (15\%), Patagifer bilobus (5\%) and E. trivolvus, respectively. Nematode (Ascaridia columbae) was found in caeca of the host, trematode parasite was observed from the rectum and cestode from the duodenum of the host birds.

The high intensity of infection was observed in autumn season. (Khan and Habibullah, 1967) disected host bird, Streptopelia decaocto and found new species of cestode Streptopeli n. sp and collected another new species of cestode E. pycnonoti $\mathrm{n}$. sp from the host Red-whiskered bulbul and only one specimen of $P$. columbiae from C. livia. Subsequently, (Dar and Tanveer, 2013) worked on three species of birds belonging to the genus; Corvus (Western jackdaw, House crow and Jungle crow host were collected of different localities of Kashmir valley but during the study they do not found any species of helminth from the present hosts. Beside the available record no systematically helminthological studies was conducted over the helminth infection of $T$, striata properly at Pakistan. Thus, the scholar chose the research work on the systematic study of the helminth parasite of present host birds. Previously no such kind of efforts were taken in this context to find out the helminth burden of Jungle babbler, helminth cause great harm to their hosts and birds are the source of pest control in many crops. Although, wild birds may be serve as disease carrying agent and may harm the domestic aves through their diet source. This kind of research study is taken first time over the helminth parasite, T. striata in Sindh, Pakistan. Therefore; the present study suggests that, more research work should be carried out on the other passeriformes for the presence of helminth parasites with systematic study, because there is no any such type of research study or record was found at district: Naushahro Feroze, Sindh.

\section{CONCLUSION}

The results of this research study indicating that host bird $T$, striata are omnivorous in their feeding habit and it is concluded that this species specially serve their life in Indian sub-continent and where they are found locally called them Sath bhai being reared on insect pest complex in agro-system consider as helpful, farmer friendly, feed many, vertebrate pests which are causative agent to damage the agricultural yields, horticulture. Similarly; they fear high intensity of helminth parasite and 
Pervasiveness and Different Characteristics of Cestode, Confluaria capillaris (Rudolphi, 1810) from Jungle babbler, Turdoides striata at Sindh, Pakistan

extreme infection rate due to this prevalence they may die or slow and gradually reducing in their population due to high mortality by infection.

\section{ACKNOWLEDGEMENTS}

The authors are highly thankful to farmers and local people of District: Naushahro Feroze to take part and the help in this kind of research work with the available sources and also provide gathered support in both season of the year to the researcher and giving them the cages for the keeping alive host birds inside them and for the certain tricks and techniques to capture these wild birds from their cultivatable fields. The authors are truly thankful to the Department of Zoology, SALU, Khairpur to provide the space for conducting research work under the laboratory conditions, without their support it was impossible to compile this research.

\section{REFERENCES}

[1] Abebe, W.T., B. Asfaw, B. Genete and P.D. Kassa. (1997). Comparative studies of external parasites and gastrointestinal helminthes of chickens kept under different management system in and around Addis Ababa. Revue de Medi. Vete., 148(6): 497-500.

[2] Adang, K.L., S.J. Oniye, A.U. Ezealor, P.A. Abdu., O.J. Ajanusi and K.P. Yoriyo. (1789). Gastrointestinal helminths of the domestic Pigeons (Columba livia domestica Gmelin, Aves: Columbidae) in Zaria, Northern Nigeria. Sci. World J., 3: 33-37.

[3] Andrew, M.I. and R.M. Naik. (1965). Structural basis of the change of eye colour of the Jungle babbler, Turdoides striatus (Dumont), during post-embryonic development. Pavo., 3: 72-74.

[4] Begum, and S. Sehrin. (2012). Gastrointestinal helminths in Pigeon, Columba livia (Gmelin, 1789). J. Asiat. Soc. Bangl. Sci., 38(1): 93-98.

[5] Bharucha, B. and G.S. Padate. (2010). Assessment of beneficial role of an insectivorous bird, Jungle babbler (Turdoides striatus) predation, on Helicoverpa armigera infesting pigeon pea (Cajanus cajan) crop. Acta Agron., 59(2): 228-235.

[6] Bhavna, B. and P. Geeta. (2010). Histological and histomorphometric study of gametogenesis in breeders and helpers of subtropical, co-operative breeder Jungle babbler. Turdoides striatus. J. Cell. Anim. Bio., (4):81-90.

[7] Bilqees, F.M., N. Khatoon and M.F. Haseeb. (2004). Neoechinorhynchotaenia sindhensis n. gen., n. sp. from the bird, Acridotheres tristis of Sindh, Pakistan. Pak. J. Zool., 36(3): 207-209.

[8] Bilqees, F.M. and N. Jehan. (1977). Helminth parasites of some birds in Sindh (Pakistan). Pakistan J. scient. ind. Res., 20: 349-358.

[9] Bilqees, F.M. and R. Rehana. (1977). Hymenolepis longirostris (Rudolphi, 1819) Railliet, 1899 (Cestoda: Hymenolepidae Fuhrmann, 1907) from Anaspl Diakou atyrhynchos in Karachi. Pakistan J. Zool., 9: 107.

[10] Bilqees, F.M. and R. Sultana. (1974). Parasites of Corvus sp. from Karachi University campus. J. Sci. Univ. Karachi, 3: 99-104.

[11] Bilqees, F.M. (1985). Cestodes of vertebrates in Pakistan. Proc. Parasitol., 1: 39-144.

[12] Connor, J.O. and M. Shrubb. (1986). Farming and birds. Cambridge University Press, Pp. 304.

[13] Dar, J.A. and S. Tanveer. (2013). Two avian cestodes parasitic to Corvus species of Kashmir, India. 5(4): 46-52.

[14] Elon, E.B. and D.J. Fred. (1924). The Helminth parasites of birds. A review of the trematode genus; Tanaisia Skrjabin. The Ameri. Midl. Nat., 34(1): 32-57.

[15] Fahimullah, (1965). Incidence of intestinal parasites of poultry in Lyallpur district. M.Sc. thesis, Agriculture University, Lyallpur.

[16] Fan, G.L., H.C. Zhou and Y.M. Xi. (2002). Pathological characteristics of a dead domestic Crested ibis in China. Jpn. J. Zoo. Wildl. Med., 5: 93-97.

[17] Gerald, D., K. Schmidt and A. Neiland. (1968). Hymenolepis (Hym.) Deblocki sp. n., and records of other helminths from charadriiform birds. Canadian J. Zool., 46(5): 1037-1040.

[18] Ghazi, R.R. and F.M. Bilqees. (2002). Neoraillietina psittaculi, n. sp. (Cestoda: Davainidae) from the avian host, Psittacula krameri Karachi, Sindh. Proceedings of Parasitology. 33: 47-56.

[19] Greenberg, R.., P. Bichier, A. Cruz Agnon, C. MacVean, R. Perez and E. Cano. (2000). The impact of avian insectivory on arthropods and leaf damage in some Guatemalan coffee plan-tations. Ecology, 81: 1750-1755.

[20] Haider, S.S., A.H. Shaikh., M.M. Saeed and T.M. Khan. (1980). A study of the helminth parasites of boiler chicken in and around Lahore. Pakistan J. Sci., 32: 44-46. 
Pervasiveness and Different Characteristics of Cestode, Confluaria capillaris (Rudolphi, 1810) from Jungle babbler, Turdoides striata at Sindh, Pakistan

[21] Henry, Y. and A.C. Burnell. (1903). A glossary of colloquial Anglo- Indian words and phrases and of kindred terms, etymological, historical, geographical and discursive. (London: John Murry). Pp. 748.

[22] Henry, Y. (1903). William Crooke ed. Hobson-Jobson: A glossary of colloquial Anglo-Indian words and phrases of kindred terms etymological, historical, geographical and discursive. London: J. Murray.

[23] Holt, R.D. and J.H. Lawton. (1994). The ecological consequences of shared natural enemies. Annu. Rev. Ecol. Syst., 25: 495-520.

[24] Joseph, J.J.R. (1968). Some Parasites of the Common Crow, Corvus brachyrhynchos Brehm, from Ohio. Canad. J. Zool., 23: 35-47.

[25] Junker, K., L. Debusho and J. Boomker. (2008). The helminth community of helmeted guineafowls, Numida meleagris (Linnaeus, 1758), in the north of Limpopo Province, South Africa. Onderstepoort J. Vet. Res., 75: 225-235.

[26] Katakam, K.K., P. Nejsum., N.C. Kyysgaard., C.B. Jorgensen and S.M. Thamsborg. (2010). Molecular and parasitological tools for the study of Ascaridia galli population dynamics in chickens. Avian Path., 39: 8185.

[27] Khan, A., R.R. Ghazi and F.M. Bilqees. (2002). Two new species of Acanthocephalan parasites of House Crow (Corvus splendens) Vieillot. Pak. J. Zoo., 34(2): 139-146.

[28] Khan, D. and Habibullah. (1967). Avian cestodes from Lahore, Pakistan. Bull. Deptt. Zool. Univ. Punjab (N.S.), 1: 1-34.

[29] Khanum, Z., M. Farooq and N. Jehan. (1982). Three new cestode genera and new species from birds of Karachi, Pakistan. Pak. J. Zool., 14: 11-19.

[30] MacArthur, R.H. and J.W. MacArthur. (1961). On bird species diversity. Ecology, 42: 594-598.

[31] Mangrio, W.M., H.A. Sahito, M. Ruk, Z.H. Shah and K.A. Kanher. (2015). Prevalence of trematode, Lyperosomum longicauda (Rudolphi, 1809) in jungle babbler, Turdoides striata (Leiothrichidae) bird at Naushahro Feroze - Sindh. $37^{\text {th }}$ All Pakistan Science Conference. Pp. 31.

[32] McJunkin, J.W., R.D. Applegat and D.A. Zelmer. (2003). Enteric helminths of juvenile and adult wild turkeys (Meleagris gallopavo) in Eastern Kansas. Avian Diseases, 47: 1481-1485.

[33] Nadeem, M., M.N. Khan, Z. Iqbal, M.S. Sajid, K. Arshad and M. Yaseen. (2007). Determinants influencing prevalence of louse infestations on layers of district Faisalabad (Pakistan). British Poultry Sci., 48(5): 546-550.

[34] Narang, M.L. and B.S. Lamba. (1986). Food habits of Jungle babbler, Turdoides striatus (Dumont) and its role in the ecosystem. Indian J. Eco., 13(1): 38-45.

[35] Pal, R.A. and K.N. Ahmed. (1985). A survey of intestinal helminths of poultry in some district of the Punjab and NWFP, Pakistan. Pakistan J. Zool., 17: 193-200.

[36] Seguel, M.D., C. Gonzalez-Acuna, C. Mathieu, Hernandez and E. Paredes. (2012). Immunosuppressive syndrome in juvenile black-faced Ibises (Theristicus melanopis melanopis) in southern Chile. Avian Dis., 56: 611-615.

[37] Sekercioglu, C.H. (2006). Increasing awareness of avian eco-logical function. Trends in Ecology and Evolution, 21: 464-471.

[38] Shuvajit, C., G. Anindita and K. Venkatraman. (2012). A new trematode parasite Zonorchis Sanglaensis n.sp (Dicrocoeliidae: Dicrocoeliinae) from a bird host Turdoides straitus orientalis (Jerdon) from Sangla, Himachal Pradesh, India trends in Parasitology research. An Inter. Peer Rev. Journal, 1(2): 1-3.

[39] Srivastava, M. (2013). Breeding behavior of Babbler, Turdoides striata as observed in a House Courtyard in Bikaner, Rajasthan (India). Poult Fish Wild Sci., 1: 104.

[40] VanBael, S.A., P. Bichier and R. Greenberg. (2007). Bird predation on insects reduces damage to the foliage of cocoa trees (Theobroma cacao) in western Panama. J. Trop. Ecology, 23: 715-719.

[41] VanBael, S.A., J.D. Brawn and S.K. Robinson. (2003). Birds defend trees from herbivores in a Neotropical forest canopy. Proceedings of the National Academy of Sciences USA, 100, 8304-8307.

[42] Western, D. and J.J.R. Grimsdell. (1979). Measuring the distribution of animals in relation to the environment.

[43] Whelan, C.J., D.G. Wenny and R.J. Marquis. (2008). Ecosystem services provided by birds. Annals New York Acad. Sci., 11(34): 25-60.

[44] Whittaker, F.H. (1973). Raillietina (R.) garciai sp. n. (Cestoda: Davaineidae) from the Greater antillean crackle, Quiscalus nigerbrachypterus Cassin, in Puerto Rico. Proceedings of the helminthological society of Washington. 40(1): 50-51.

[45] Xi, Y.M., B.Z. Lu., Y.M. Zhang and N. Fujihara. (2002). Restoration of the crested ibis, Nipponia nippon. J. Appl. Anim. Res., 22: 193-200. 
Pervasiveness and Different Characteristics of Cestode, Confluaria capillaris (Rudolphi, 1810) from Jungle babbler, Turdoides striata at Sindh, Pakistan

[46] Yazdanbakhsh, M., P.G. Kremsner and R. vanRee. (2002). Allergy, parasites, and the hygiene hypothesis. Science, 296: 490-494.

[47] Yousaf, J.A. and M.R. Baig. (1974). Observations on the helminth parasites of poultry in Peshawar. Pakistan J. Anim. Sci., 10: 37-39.

[48] Zhou, H., G. Fan, Y. Cao, W. Fu, B. Lu and Y. Xi. (2000). The pathological diagnosis of the death of a domesticated Crested ibis. Acta. Univ. Agric., (China). 28: 60-64.

Citation: W. M. Mangrio et al., "Pervasiveness and Different Characteristics of Cestode, Confluaria capillaris (Rudolphi, 1810) from Jungle babbler, Turdoides striata at Sindh, Pakistan ", International Journal of Research Studies in Zoology, vol.3, no.3,p.33-43, 2017. http://dx.doi.org/10.20431/2454-941X.0303005

Copyright: () 2017 Authors. This is an open-access article distributed under the terms of the Creative Commons Attribution License, which permits unrestricted use, distribution, and reproduction in any medium, provided the original author and source are credited. 